\title{
Expression and significance of Pin1, $\beta$-catenin and cyclin D1 in hepatocellular carcinoma
}

\author{
RAN AO $^{1}$, DAO-RONG ZHANG ${ }^{2,3}$, YA-QI DU ${ }^{1}$ and YING WANG ${ }^{1}$ \\ Departments of ${ }^{1}$ Gastroenterology and ${ }^{2}$ Pathophysiology, The First Affiliated Hospital of China Medical University; \\ ${ }^{3}$ Department of Pathophysiology, College of Basic Medical Sciences, China Medical University, \\ Shenyang, Liaoning 110001, P.R. China
}

Received September 25, 2013; Accepted May 15, 2014

DOI: $10.3892 / \mathrm{mmr} .2014 .2456$

\begin{abstract}
The aim of the present study was to examine the expression and significance of peptidyl-prolyl cis-trans isomerase NIMA-interacting 1 (Pin1), $\beta$-catenin and cyclin D1 in hepatocellular carcinoma (HCC). A total of 24 samples of HCC and adjacent normal tissues were analyzed. The expression of Pin1, $\beta$-catenin and cyclin D1 in HCC were detected using immunohistochemistry, western blot analysis, polymerase chain reaction and immunofluorescence. The expression of Pin1, $\beta$-catenin and cyclin D1 in HCC tissues were significantly higher than that in adjacent tissues. Pin1 was not markedly expressed in the adjacent normal tissues, while expression in the cytoplasm and nucleus of HCC cells was high. However, $\beta$-catenin and cyclin D1 only revealed a weak expression in the cytoplasm and nucleus of HCC cells. Immunoprecipitation analyses demonstrated two clear bands at 19 and $34 \mathrm{kDa}$, and a brown band at $55 \mathrm{kDa}$ as expected. Immunofluorescence analysis of HCC cells indicated that Pin1 was present in the cytoplasm and nucleus, and $\beta$-catenin and cyclin D1 were present in the nucleus. In conclusion, the present study indicated that Pin1, $\beta$-catenin and cyclin D1 were highly expressed in HCC. Therefore, detection of the expression of Pin $1, \beta$-catenin and cyclin D1 may be useful for the development of novel diagnostic and treatment strategies for HCC.
\end{abstract}

\section{Introduction}

Hepatocellular carcinoma (HCC) is the fifth most common cancer type in males and the second leading cause of cancer-associated mortality. An estimated 748,300 new HCC cases and 695,900 cancer-associated mortalities occurred worldwide in 2008 (1). The pathways of HCC development are heterogeneous and affected by various genetic and environmental factors, including

Correspondence to: Dr Dao-Rong Zhang, Department of Pathophysiology, College of Basic Medical Sciences, China Medical University, 92 North Second Road, Heping, Shenyang, Liaoning 110001, P.R. China

E-mail: cmulh_ar@126.com

Key words: Pin1, $\beta$-catenin, cyclin D1, hepatocellular carcinoma chronic hepatitis B virus (HBV) and hepatitis $\mathrm{C}$ virus (HCV) infections, cirrhosis, chronic alcohol use, aflatoxin ingestion and fatty liver disease (2-4). HBV and HCV infections increase the risk of developing cirrhosis and, subsequently, HCC. Among the $\mathrm{HCC}$ cases associated with cirrhosis, $\mathrm{HCV}$ infection has been identified in $27-73 \%$ and HBV infection in $12-55 \%$ (5-7). To date, a wide range of proteins that demonstrated high expression levels in HCC tissue have been identified, including Pin1, $\beta$-catenin and cyclin D1 $(8,9)$.

Peptidyl-prolyl cis-trans isomerase NIMA-interacting 1 (Pin1), a peptidyl-prolyl isomerase, is a member of the peptidylprolyl isomerase (PPIase)-parvulin family, which acts to specifically recognize phosphorylated serine/threonine-proline motifs (10). Pin1-catalyzed isomerization has an important role in the control of normal cellular functions. Pin1 also induces conformational changes in its target phosphoproteins that are able to modulate the stability, localization and function of numerous Pin1 targets involved in tumor progression $(11,12)$. Pin 1 is overexpressed at a particularly high frequency in numerous different tumors, including highly common human cancer types, such as prostate, lung, liver and brain tumors (13). Although the relevance of Pin1 underexpression in $\mathrm{HCC}$ has not been examined, the effect of differential Pin1 levels on tumor progression likely depends on the specific repertoire of genetic mutations acquired by cancer cells $(9,14)$. Pin1 overexpression correlates with the deregulation of cyclin D1, which is possibly the result of the enhanced transcription of this gene by c-Jun and $\beta$-catenin, as well as post-translational stabilization of the protein (15). Pang et al (16) demonstrated that Pin1 overexpression conferred tumorigenic properties on an immortalized human HCC cell line. Therefore, Pin1 overexpression may be an independent marker for predicting the probability of recurrence in HCC.

$\beta$-catenin functions in a dual manner in epithelial cells, depending on intracellular localization (17). At the plasma membrane, $\beta$-catenin is an important component of adherent junctions, acting in cell-cell adhesion by linking E-cadherin, in conjunction with $\alpha$-catenin, to the actin cytoskeleton. In addition, $\beta$-catenin also acts as the main effector of the canonical Wnt signaling cascade in the nucleus (18). The canonical Wnt pathway functions by regulating the amount of the transcriptional coactivator $\beta$-catenin, which controls key developmental gene expression programs (19). Wnt/ $\beta$-catenin 
signaling is known for its role in embryogenesis as well as carcinogenesis (20). In the liver, $\beta$-catenin signaling is critical during hepatic development and regeneration, and its dysregulation is evident in aberrant hepatic growth in various liver tumor types (21). Its predominant cellular roles in the liver include regulating the processes of cell proliferation, apoptosis, oxidative stress and differentiation, which in turn contribute to hepatic growth, zonation, xenobiotic metabolism and other metabolic processes inherent to the liver (22).

Cyclin D1 is a cell cycle regulator that drives cell cycle progression from $\mathrm{G} 1$ to $\mathrm{S}$ phase; the aberrant expression of cyclin D1 may lead to the proliferation and invasion of tumor cells (23). Previous studies have indicated that cyclin D1 has an important role in regenerating HCC and numerous other types of cancer (24). Cyclin D1 directly enhances estrogen receptor activity and inhibits androgen receptor activity in a ligand-independent manner, and may therefore have an important role in hormone-responsive malignancies $(25,26)$. Hepatic expression of cyclin D1 leads to increased serum estradiol levels, increased estrogen-responsive gene expression and decreased androgen-responsive gene expression (27). Cyclin D1 may also regulate the activity of several key enzymatic reactions in the liver, including increased oxidation of testosterone to androstenedione and decreased conversion of estradiol to estrone (28).

Pang and Poon (29) have found that $>50 \%$ of HCCs exhibit a high expression of Pin1 and 70\% of HCCs have an abnormal accumulation of $\beta$-catenin, with a common accumulation of $\beta$-catenin and cyclin D1 accounting for $68 \%$ of HCCs. These results indicate that an overexpression of Pin1 may promote abnormal accumulation of $\beta$-catenin and overexpression of cyclin D1. This hypothesis is consistent with the conclusion that the abnormal accumulation of $\beta$-catenin resulted from Pin 1 inhibiting the combination of APC and $\beta$-catenin. However, the majority of previous studies on Pin 1 are limited to breast cancer, with few examining its role in HCC. Therefore, the present study aimed to more broadly define the expression and significance of Pin1, $\beta$-catenin and cyclin D1 in HCC tissues.

\section{Materials and methods}

Materials. A total of 24 formalin-fixed, paraffin-embedded, surgically resected cases of HCC and adjacent normal tissues were retrieved from The First Affiliated Hospital of China Medical University General Surgery (Shenyang, China), which were collected from May 1st, 2011 to September 1st,2013. A total of 12 fresh specimens of $\mathrm{HCC}$ and adjacent normal tissue were stored at $-80^{\circ} \mathrm{C}$ until use. The human hepatoma cell line Bel7402 was derived from the Chinese Department of Medical Genetics. The current study was approved by the ethics committee of The First Affiliated Hospital of China Medical University General Surgery (Shenyang, China). All patients gave written signed informed consent at the time of hospitalization.

Immunohistochemistry. Concentrated Pin1 polyclonal antibodies, monoclonal antibodies cyclin D1 and gradient protein were all purchased from Santa Cruz Biotechnology, Inc. (Santa Cruz, CA, USA). Ready-to-use immunohistochemistry hypersensitivity, DAB chromogenic enzyme substrate kit and $\beta$-catenin type and concentration of an anti-horseradish peroxidase-labeled goat anti-rabbit immunoglobulin (Ig)G secondary antibody were purchased from Beijing Biotechnology Co. (Beijing, China) Total RNA extraction kits were purchased from Huamei Co. (Beijing, China) and agarose was obtained from Promega Corp. (Madison, WI, USA). The polymerase chain reaction (PCR) robot thermocycler was purchased from Biometra Co. (Goettingen, Germany). The ultraviolet spectrophotometer UA-1201 was from Shimadzu, (Kyoto, Japan) and the GL212Pro Gel imaging analysis system was purchased from (Carestream Health, Inc., Rochester, NY, USA).

Immunohistochemistry. The expression of Pin 1 and $\beta$-catenin was determined by streptomycin avidin-peroxidase (SP) connection. The expression of Pin1 protein was then mapped to the cytoplasm and (or) the nucleus. Staining intensity was scored the following: 0 , indicated no staining; 1 , pale yellow; 2 , brown and $3, \tan ($ dark brown). The average percentage of positive cells was converted to a four-tier numeric score $(0,<25 \% ; 1,25-49 \%$; $2,50-74 \% ; 3, \geq 75)$. The final score was determined by multiplying the above two scores ( $\geq 3$, overexpression). Positive expression of $\beta$-catenin in normal epithelial tissue was mapped to the cell membranes, but rarely to the cytoplasm. A score $\geq 10 \%$ in the cytoplasm and (or) the nuclei of cells was noted as positive expression to the extend of abnormal accumulation. The scanned slides were independently analyzed by two high senior pathologists, and when their findings were inconsistent, consensus was reached through re-evaluation and discussion. Cyclin D1 protein was located in the cytoplasm and (or) the nucleus. A lack of significantly positive cells was regarded as negative $(-),<20 \%$ positive cells was regarded as weakly positive $(+)$ and $>20 \%$ positive cells was regarded as positive $(++)$.

Western blot analysis. The analysis buffer $(50 \mathrm{mM}$ Tris- $\mathrm{HCl}$; $\mathrm{pH} 7.4,150 \mathrm{mM} \mathrm{NaCl}, 1 \% \mathrm{NP}-40$ and $0.1 \%$ SDS) was overlaid five times on top of a fresh sample, which was then cut into sections and subjected to ultrasonic treatment. The supernatant protein was extracted using high-speed centrifugation, electrophoresis, transfer, adding of primary ( $\beta$ actin) and secondary (horseradish peroxidase-labeled goat anti-rabbit $\operatorname{IgG}$ ) antibodies and DAB chromogenic reagent kit (Beijing Zhongshan Golden Bridge Biotechnology Co., Ltd., Beijing, China. As a result, the DNA bands were able to be viewed clearly on the transfer film.

$P C R$. Total RNA was extracted from exponentially growing cells using TRIzol ${ }^{\mathrm{TM}}$ reagent (Invitrogen Life Technologies, Carlsbad, CA, USA). A total of $5 \mu \mathrm{g}$ total RNA was reverse transcribed using M-MLV reverse transcriptase (N8080018; Invitrogen Life Technologies) and then Pin1, $\beta$-catenin and cyclin D1 were amplified. GAPDH was amplified simultaneously as an internal reference. Each sample was repeated at least three times. First-strand cDNA was synthesized from $2 \mu \mathrm{l}$ total RNA by adding $10 \mu \mathrm{l} 2 \mathrm{X}$ buffer, $4 \mu \mathrm{l} \mathrm{MgSO}_{4}, 0.5 \mu \mathrm{l}$ dNTP (10 mmol), $0.5 \mu$ l oligo(dT) 15, $0.25 \mu 1$ double-distilled (dd) $\mathrm{H}_{2} \mathrm{O}$ and $0.25 \mu \mathrm{l}$ RNase-inhibitor. The denaturation step of the asymmetric PCR was performed at $94^{\circ} \mathrm{C}$ for $30 \mathrm{sec}$. A total of 35 cycles of denaturation $\left(30 \mathrm{sec}, 94^{\circ} \mathrm{C}\right.$ ), annealing ( $30 \mathrm{sec}$, $\left.55^{\circ} \mathrm{C}\right)$ and extension $\left(20 \mathrm{sec}, 70^{\circ} \mathrm{C}\right)$ were performed. The annealing temperature of the internal reference gene GAPDH was $62^{\circ} \mathrm{C}$. PCR amplification was performed in a total volume of $3 \mu \mathrm{l}$ cDNA, consisting of $2.5 \mu \mathrm{l}$ of 10X PCR buffer ( $50 \mathrm{mM}$ Tris-HCl; $\mathrm{pH} 7.4,150 \mathrm{mM} \mathrm{NaCl}, 1 \% \mathrm{NP}-40$ and $0.1 \%$ SDS), 
Table I. Polymerase chain reaction primer sequences of Pin1, $\beta$-catenin and cyclin D1.

\begin{tabular}{|c|c|c|}
\hline Primer & Nucleotide sequence & Length (bp \\
\hline Pin1 & $\begin{array}{l}\text { 5'-GGATCCATGGCGGACGAGGAGAAG-3' } \\
\text { 5'-GAATTCTCACTCAGTGCGGAGGATG-3' }\end{array}$ & 492 \\
\hline Cyclin D1 & $\begin{array}{l}\text { 5'-ACCAGCTCCTGTGCTGCGAA-3' } \\
\text { 5'-CAGGACCTCCTTCTGCACAC-3' }\end{array}$ & 455 \\
\hline$\beta$-catenin & $\begin{array}{l}\text { 5'-TCTCCCAAGAAACCTGACTCAA-3' } \\
\text { 5'-TCССТССССТCCACAAAA-3' }\end{array}$ & 310 \\
\hline$\beta$-actin & $\begin{array}{l}\text { 5'-AGCAGAGAATGGAAAGTCAAA-3' } \\
\text { 5'-ATGCTGCTTACATGTCTCGAT-3' }\end{array}$ & 226 \\
\hline
\end{tabular}

Table II. Expression of Pin1, $\beta$-catenin and cyclin D1 mRNA in HCC cells before and after transfection.

\begin{tabular}{|c|c|c|c|c|c|}
\hline \multicolumn{2}{|c|}{ Pin1 } & \multicolumn{2}{|c|}{$\beta$-catenin } & \multicolumn{2}{|c|}{ Cyclin D1 } \\
\hline Before & After & Before & After & Before & After \\
\hline $0.55 \pm 0.05$ & $2.21 \pm 0.03$ & $0.38 \pm 0.02$ & $1.35 \pm 0.05$ & $0.32 \pm 0.04$ & $1.37 \pm 0.05$ \\
\hline
\end{tabular}

HCC, hepatocellular carcinoma.

$2 \mu \mathrm{dNTP}(2.5 \mathrm{mM}), 1.5 \mu \mathrm{l}$ sense and antisense of each primer,

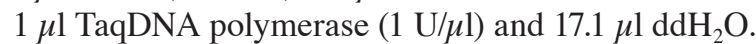

Following amplification, the PCR products were scanned by the Gel oc1000 imaging system (Bio-Rad, Hercules, CA, USA), analyzed using agarose gel electrophoresis analysis (10 g/l metaphor agarose gel) and stained with ethidium bromide (EB). The comparison between the integral A value of the sample bands and the corresponding $\beta$-actin mRNA represented the relative amount of mRNA in the sample (Table I). Electrophoresis was scanned using a BioDoc-It Imaging System (UVP, Inc., Upland, CA, USA).

Cell culture and transfection. Bel7402 cells were cultured and supplemented with $10 \%$ fetal calf serum, $100 \mu \mathrm{g} / \mathrm{ml}$ streptomycin, 100 international $\mathrm{U} / \mathrm{ml}$ penicillin and $0.286 \mathrm{~g} / \mathrm{ml}$ glutamine at (Gibco-Invitrogen, Carlsbad, CA, USA) at $37^{\circ} \mathrm{C}$ in a humidified $5 \% \mathrm{CO}_{2}$ atmosphere. The medium was changed every day depending on the cell growth and the cells were detached with $0.25 \%$ trypsin until cell growth was stable at the logarithmic phase. Morphological changes of cultured cells were observed under an inverted microscope. The resulting DNA was used to transfect plasmid IPO 2000. Pin1 plasmids and primers were synthesized and identified by Takara Bio, Inc. (Shiga, Japan). The primers of $\beta$-catenin and cyclin D1 were synthesized by Shanghai Sangon Co., Ltd. (Shanghai, China).

Immunofluorescence. The cultured endothelial cells were grown on culture plates on a sterilized coverslip for $48 \mathrm{~h}$ following transfection for 2-24 h. The cells were then rinsed three times with phosphate-buffered saline (PBS) and fixed in $4 \%(\mathrm{v} / \mathrm{v})$ paraformaldehyde/PBS by incubation for $15 \mathrm{~min}$ at $37^{\circ} \mathrm{C}$ with $3 \%$ hydrogen peroxide to block endogenous peroxidase. Next, they were rinsed three times with PBS by incubation for $1 \mathrm{~h}$ at room temperature and were then incubated with the primary antibody ( $\beta$ actin) at $4^{\circ} \mathrm{C}$ overnight. The cells were rinsed three times for $10 \mathrm{~min}$ with PBS by incubation for $30 \mathrm{~min}$ with the secondary antibody. Then, they were rinsed three times for 10 min with PBS and two times for 5 min with DW2, and mounted in glycerol. Finally, the cells were observed under a Olympus BX60 fluorescent microscope (Olympus Corporation, Tokyo, Japan).

Co-immunoprecipitation. The cells were rinsed two or three times with PBS and then the PBS buffer was removed. Next, RIPA lysis buffer (200 mM NaCl, $50 \mathrm{mM}$ Tris- $\mathrm{HCl}, \mathrm{pH} 7.5$, $10 \mathrm{mM} \mathrm{MgCl} 2,1 \%$ Triton X-100, 0.1\% SDS, $0.5 \%$ deoxycholate, $5 \%$ glycerol, $1 \mathrm{mM}$ phenylmethylsulfonyl fluoride, $9 \mathrm{nM}$ pepstatin, $9 \mathrm{nM}$ antipain, $10 \mathrm{nM}$ leupeptin, and $10 \mathrm{nM}$ chymostatin) was added $\left(10^{7}\right.$ cells $\left./ \mathrm{ml}\right)$ and cells were scraped and collected in centrifuge tubes and incubated at $4^{\circ} \mathrm{C}$ for $15 \mathrm{~min}$ in lysis buffer. The solution in each tube was centrifuged at $14,000 \mathrm{x} g$ for $15 \mathrm{~min}$ and the supernatant, which contained the protein, was then removed from the new tubes. Then, $100 \mu 1$ agarose beads were added to the cellular proteins, agitated at $4^{\circ} \mathrm{C}$ for $2 \mathrm{~h}$, centrifuged at $14,000 \mathrm{x}$ g for $10 \mathrm{~min}$, and the supernatant was collected to detect the protein concentration. Each sample was adjusted to the same protein concentration $(10 \mu \mathrm{g} / \mathrm{ml})$, the primary antibody ( $\beta$ actin) was added to $500 \mu \mathrm{l}$ cell lysates and agitated at $4^{\circ} \mathrm{C}$ for $2 \mathrm{~h}$. Subsequently, $100 \mu \mathrm{l}$ $50 \%$ sepharose beads were added and agitated at $4^{\circ} \mathrm{C}$ for $2 \mathrm{~h}$. The sepharose beads were collected by centrifugation at 14,000 rpm for $5 \mathrm{sec}$ and the supernatant was discarded. The sepharose beads were rinsed three times with $800 \mu \mathrm{l}$ PBS and they were then collected, after which they were suspended in $60 \mu \mathrm{l}$ sample buffer (50 mM Tris-HCl; $\mathrm{pH} 7.4,150 \mathrm{mM} \mathrm{NaCl}$, $1 \%$ NP-40 and $0.1 \%$ SDS) and centrifuged following $5 \mathrm{~min}$ in a 
Table III. Difference in expression levels between Pin1 and $\beta$-catenin.

\begin{tabular}{lccrr}
\hline & & \multicolumn{2}{c}{$\beta$-catenin } & \\
\cline { 3 - 3 } & \multirow{2}{*}{ Expression levels } & Low & High & P-value \\
\hline Pin1 & Low & 6 & 3 & 0.467 \\
& High & 3 & 12 & \\
\hline
\end{tabular}

Table IV. The difference in expression levels between Pin1 and cyclin D1.

\begin{tabular}{ccccc}
\hline & & \multicolumn{2}{c}{ Cyclin D1 } & \\
\cline { 3 - 4 } & Expression levels & Low & High & P-value \\
\hline Pin1 & Low & 5 & 2 & 0.597 \\
& High & 2 & 15 & \\
\hline
\end{tabular}
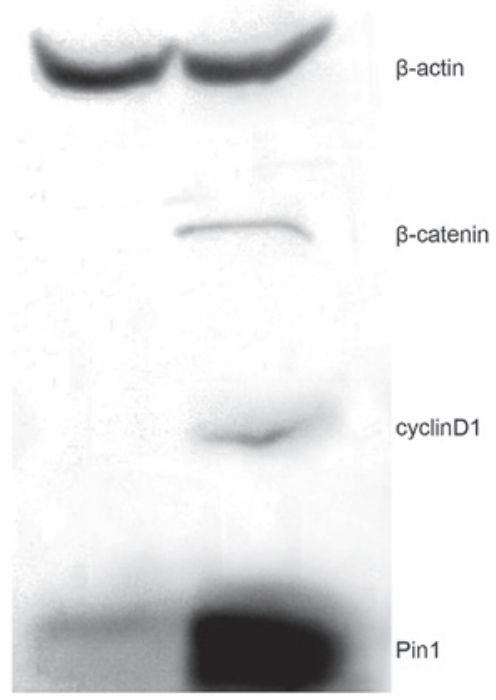

Figure 1. Representative western blot of 24 experiments indicating expression of Pin1, cyclin D1 and $\beta$-catenin in HCC (right lane) and adjacent normal tissues (left lane). HCC, hepatocellular carcinoma.

boiling water bath, to run electrophoresis. Finally, clear bands appeared at 19 and $34 \mathrm{kDa}$, which indicated the precipitation of immune complexes.

Statistical analysis. All statistical analyses were performed using the SPSS 18.0 software (SPSS, Inc., Chicago, IL, USA). A $\chi^{2}$ test was used to compare the frequencies. One-way analysis of variance and Student's t-test were used for the normally distributed variables, whereas the Mann-Whitney U test was used for the non-normally distributed variables. Comparisons between the two groups for nominal variables were performed using Fisher's exact test. All of the tests of statistical significance were two-sided. $\mathrm{P}<0.05$ was considered to indicate a statistically significant difference between values.
Table V. Difference in expression levels between $\beta$-catenin and cyclin D1.

\begin{tabular}{|c|c|c|c|c|}
\hline & \multirow[b]{2}{*}{ Expression levels } & \multicolumn{2}{|c|}{$\beta$-catenin } & \multirow[b]{2}{*}{ P-value } \\
\hline & & Low & High & \\
\hline \multirow[t]{2}{*}{ Cyclin D1 } & Low & 4 & 2 & 0.408 \\
\hline & High & 4 & 14 & \\
\hline
\end{tabular}

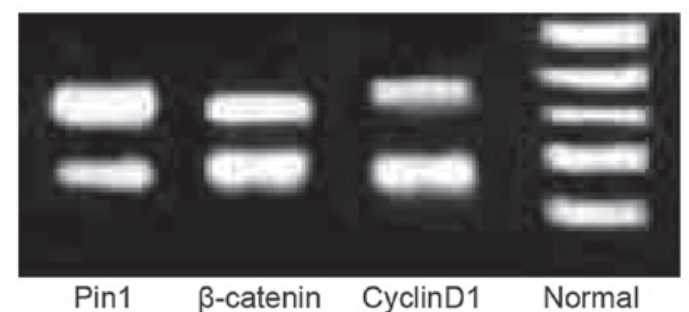

Figure 2. Expressions of Pin1, cyclin D1 and $\beta$-catenin mRNA in HCC and adjacent normal tissues were detected using quantitative polymerase chain reaction analysis. $\mathrm{HCC}$, hepatocellular carcinoma.

\section{$55 \mathrm{kDa}$}

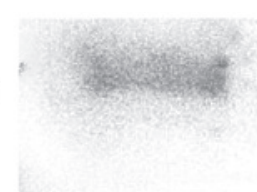

$42 \mathrm{kDa}$

$35 \mathrm{kDa}$

$34 \mathrm{kDa}$

$28 \mathrm{kDa}$

$19 \mathrm{kDa}$

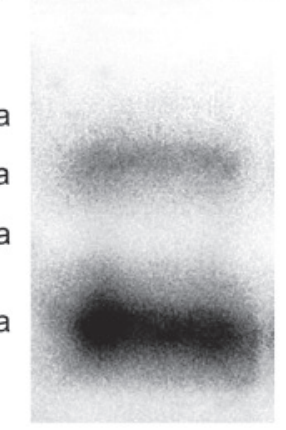

Figure 3. Immunoprecipitation analyses of Pin1, cyclin D1 and $\beta$-catenin in HCC tissues. HCC, hepatocellular carcinoma.

\section{Results}

Pinl protein is highly expressed in nuclei and cytoplasm of HCC cells, but not in normal tissues. The expression of Pin1, cyclin D1 and $\beta$-catenin in HCC and adjacent normal tissues are shown in Fig. 1. Pin1 demonstrated no expression in the adjacent normal tissues, but a strongly positive expression in the cytoplasm and nuclei of HCC cells. Out of 24 cases of HCC specimens analyzed, 66.7\% (16/24) demonstrated a strong positive Pin1 expression and 58.3\% (14/24) revealed a nuclear expression. However, $\beta$-catenin was weakly expressed in the cytoplasm and nuclei of HCC cells. No expression of $\beta$-catenin was identified in the adjacent normal tissues. Similarly, cyclin D1 also demonstrated a weak expression in the cytoplasm and nuclei of HCC cells, but no expression in 

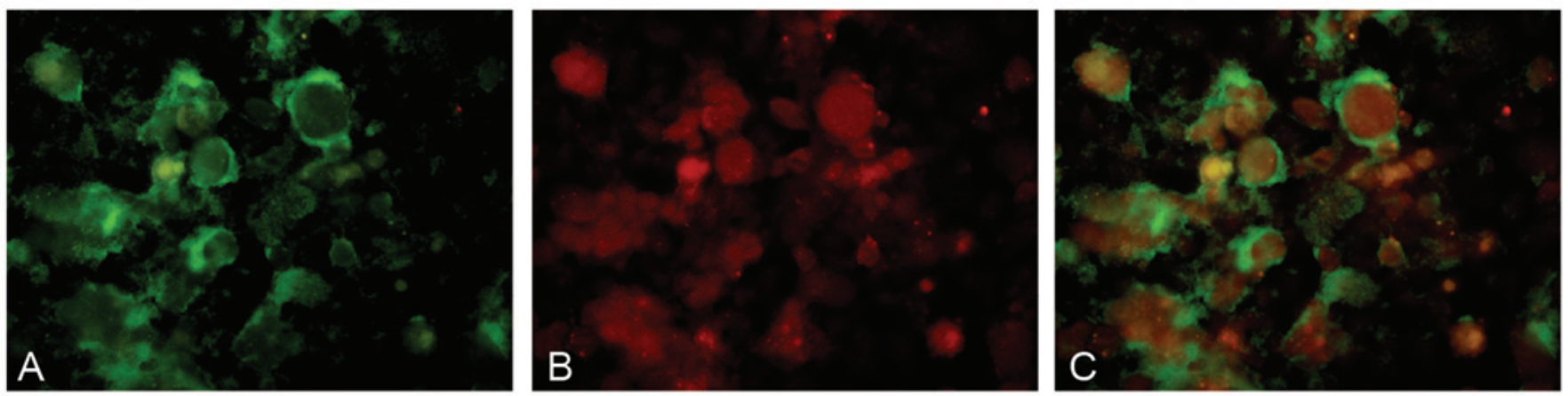

Figure 4. Immunofluorescence analysis of Pin1 and $\beta$-catenin in HCC cells. (A) Incubated with anti-Pin1 antibodies; (B) incubated with anti- $\beta$-catenin antibodies; (C) incubated with anti-Pin1 and anti- $\beta$-catenin antibodies. Magnification, x1000. HCC, hepatocellular carcinoma.
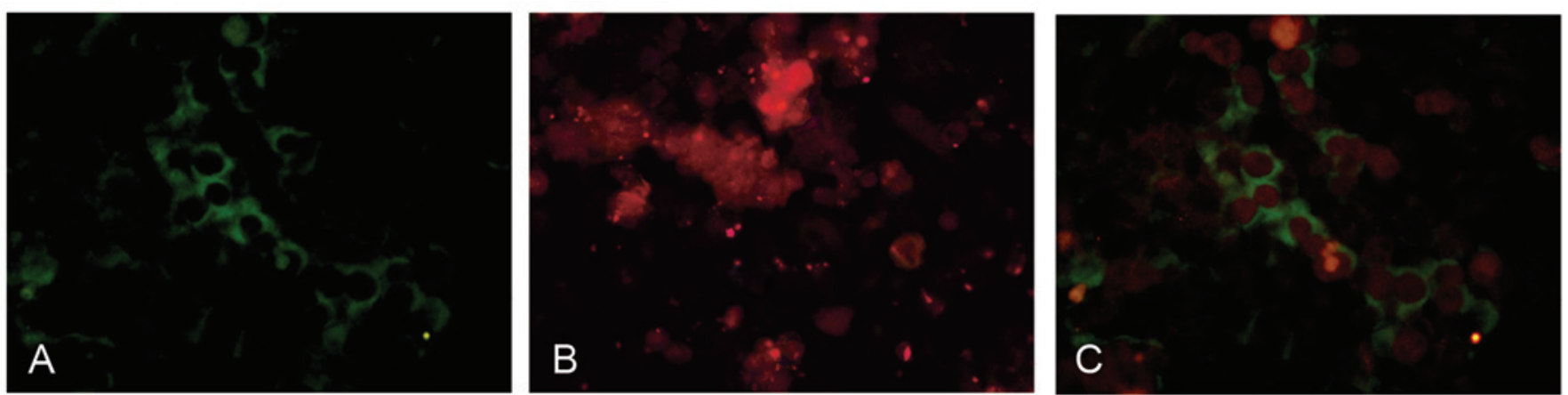

Figure 5. Immunofluorescence analysis of Pin1 and cyclin D1 in HCC cells. (A) Incubated with anti-Pin1 antibodies; (B) incubated with anti-cyclin D1 antibodies; (C) incubated with anti-Pin1 and anti-cyclin D1 antibodies. Magnification, x1000. HCC, hepatocellular carcinoma.

the adjacent tissues. A total of 79.2\% (19/24) of the HCC specimens demonstrated a weakly positive expression of cyclin D1, including $33.3 \%(8 / 24)$ in the nuclei of HCC cells.

mRNA levels of Pinl, cyclin Dl and $\beta$-catenin in HCC are higher than in normal tissue. The expression levels of Pin1, cyclin D1 and $\beta$-catenin mRNA in HCC cell lines were significantly higher than those in the adjacent normal tissues (Fig. 2 and Table II). The associations between Pin1, $\beta$-catenin and cyclin D1 are summarized in Tables III-V. The results revealed that there were no significant difference between Pin1, $\beta$-catenin and cyclin D1 expression levels (all $\mathrm{P}>0.05$ ).

Immunoprecipitation identifies Pin1, $\beta$-catenin and cyclin D1 protein in HCC cells. Immunoprecipitation analyses demonstrated two clear bands at 19 and $34 \mathrm{kDa}$ and a brown band at $55 \mathrm{kDa}$ as expected (Fig. 3). Immunofluorescence analysis of HCC cells indicated that Pin1 was present in the cytoplasm and nucleus, and $\beta$-catenin and cyclin D1 were present in the nucleus.

Pinl is present in the cytoplasm and nuclei, while $\beta$-catenin and cyclin DI are located in the nuclei of HCC cells. Immunofluorescence images of HCC cells showed that Pin1 demonstrated green fluorescence in the cytoplasm and nuclei, while $\beta$-catenin and cyclin D1 revealed red fluorescence in the nuclei (Figs. 4 and 5).

\section{Discussion}

The present study indicated that Pin1, $\beta$-catenin and cyclin D1 are closely correlated with HCC (30). Pin1, cyclin D1 and $\beta$-catenin expression in $\mathrm{HCC}$ were identified to be significantly higher than in the corresponding adjacent normal tissues, using western blot analysis and PCR. There was a high expression of Pin $1, \beta$-catenin and cyclin D1 in HCC cells. However, Pin1, cyclin D1 and $\beta$-catenin demonstrated no expression in adjacent normal tissues, as determined by immunohistochemistry and western blot analysis. The expression levels of Pin1, $\beta$-catenin and cyclin D1 in HCC tissues were significantly higher than in the adjacent normal tissues, suggesting that the overexpression of Pin1, $\beta$-catenin and cyclin D1 may provide a novel strategy for the diagnosis and treatment of HCC.

Pin1 is an essential PPIase which, in contrast to other phosphoprotein-binding proteins, binds and regulates mitosis-specific phosphoproteins and has intrinsic prolyl isomerase activity (31). There is a two-step mechanism for mitotic regulation. The first event is phosphorylation at specific Ser-Pro or Thr-Pro sites by the mitosis-specific activation of Ser/Thr kinases, creating binding sites for Pin1. Secondly, Pin1 binds to the phosphorylated Ser/Thr-Pro motifs and induces local conformational changes through prolyl isomerization (32). Therefore, this suggests that the interaction of Pin1 and its targets is involved in regulating the cell cycle and depends on mitotic phosphorylation, demonstrating that 
specific phosphorylation is an important signal transduction mechanism (33). $\beta$-catenin is an important regulator of cell proliferation and differentiation, and coordinates the mediation of cell-cell adhesion and gene transcription (31). $\beta$-catenin acts in the Wnt signaling pathway, which activates the transcription of crucial target genes responsible for cellular proliferation and differentiation, controls E-cadherin-mediated cell adhesion at the plasma membrane and mediates the interplay of adherent junction molecules with the actin cytoskeleton (31). Numerous previous studies have suggested that Pin1 and $\beta$-catenin have important roles in promoting the development of HCC by stimulating tumor cell proliferation and reducing the activity of cell adhesion systems, and is thus associated with poor prognosis, particularly in patients with poorly differentiated $\operatorname{HCC}(8,9,34)$. Cyclin D1 has also been implicated most prominently in oncogenesis among the key cell cycle regulators which are overexpressed in numerous tumor types (35). A number of studies have demonstrated that Pin1 overexpression appears to be a mutually exclusive event, leading to $\beta$-catenin and cyclin D1 accumulation in HCC. The present study indicated that Pin1, $\beta$-catenin and cyclin D were highly expressed in HCC tissues, but not in the adjacent normal tissues. Although the exact role of Pin1, $\beta$-catenin and cyclin D1 in the development of HCC has yet to be elucidated, one possible reason for this result may be that overexpression of Pin $1, \beta$-catenin and cyclin D1 is associated with changes in the expression and function of cytokines and thereby affects the development and progression of HCC.

In conclusion, the present study indicated that Pin1, $\beta$-catenin and cyclin D1 may be highly expressed in HCC. Therefore, detection of the expression of Pin $1, \beta$-catenin and cyclin D1 may be useful for the development of novel diagnostic and treatment strategies for HCC.

\section{Acknowledgements}

This study was funded by the Scientific Research of the First Hospital of China Medical University (fsfh1313).

\section{References}

1. Jemal A, Bray F, Center MM, et al: Global cancer statistics. CA Cancer J Clin 61: 69-90, 2011.

2. Ascha MS, Hanouneh IA, Lopez R, et al: The incidence and risk factors of hepatocellular carcinoma in patients with nonalcoholic steatohepatitis. Hepatology 51: 1972-1978, 2010.

3. Severi T, van Malenstein H, Verslype C and van Pelt JF: Tumor initiation and progression in hepatocellular carcinoma: risk factors, classification, and therapeutic targets. Acta Pharmacol Sin 31: 1409-1420, 2010.

4. Liu Y, Pan S, Liu L, et al: A genetic variant in long non-coding RNA HULC contributes to risk of HBV-related hepatocellular carcinoma in a Chinese population. PloS One 7: e35145, 2012.

5. Kang TW, Yevsa T, Woller N, et al: Senescence surveillance of pre-malignant hepatocytes limits liver cancer development. Nature 479: 547-551, 2011.

6. Kanwal F, Hoang T, Kramer JR, et al: Increasing prevalence of HCC and cirrhosis in patients with chronic hepatitis $\mathrm{C}$ virus infection. Gastroenterology 140: 1182-1188, 2011.

7. Nguyen VT, Law MG and Dore GJ: Hepatitis B-related hepatocellular carcinoma: epidemiological characteristics and disease burden. J Viral Hepat 16: 453-463, 2009.

8. Nejak-Bowen KN, Thompson MD, Singh S, et al: Accelerated liver regeneration and hepatocarcinogenesis in mice overexpressing serine-45 mutant beta-catenin. Hepatology 51: 1603-1613, 2010.

9. Cheng CW, Chow AK, Pang R, et al: PIN1 inhibits apoptosis in hepatocellular carcinoma through modulation of the antiapoptotic function of survivin. Am J Pathol 182: 765-775, 2013.
10. Abrahamsen H, O'Neill AK, Kannan N, et al: Peptidyl-prolyl isomerase Pin1 controls down-regulation of conventional protein kinase C isozymes. J Biol Chem 287: 13262-13278, 2012.

11. Bao L, Kimzey A, Sauter G, et al: Prevalent overexpression of prolyl isomerase Pin1 in human cancers. Am J Pathol 164: 1727-1737, 2004.

12. Aluise CD, Rose $\mathrm{K}$, Boiani $\mathrm{M}$, et al: Peptidyl-prolyl cis/trans-isomerase A1 (Pin1) is a target for modification by lipid electrophiles. Chem Res Toxicol 26: 270-279, 2013.

13. Tabarés-Seisdedos R and Rubenstein JL: Inverse cancer comorbidity: a serendipitous opportunity to gain insight into CNS disorders. Nat Rev Neurosci 14: 293-304, 2013.

14. Lu KP and Zhou XZ: The prolyl isomerase PIN1: a pivotal new twist in phosphorylation signalling and disease. Nat Rev Mol Cell Biol 8: 904-916, 2007.

15. Teng BL, Hacker KE, Chen S, et al: Tumor suppressive activity of prolyl isomerase Pin1 in renal cell carcinoma. Mol Oncol 5: 465-474, 2011.

16. Pang RW, Lee TK, Man K, et al: PIN1 expression contributes to hepatic carcinogenesis. J Pathol 210: 19-25, 2006.

17. Maher MT, Flozak AS, Stocker AM, et al: Activity of the beta-catenin phosphodestruction complex at cell-cell contacts is enhanced by cadherin-based adhesion. J Cell Biol 186: 219-228, 2009.

18. Schmalhofer O, Brabletz $\mathrm{S}$ and Brabletz T: E-cadherin, beta-catenin, and ZEB1 in malignant progression of cancer. Cancer Metastasis Rev 28: 151-166, 2009.

19. Clevers $H$ and Nusse R: Wnt $/ \beta$-catenin signaling and disease. Cell 149: 1192-1205, 2012.

20. Stein TJ, Jochem A, Holmes KE and Sandgren EP: Effect of mutant $\beta$-catenin on liver growth homeostasis and hepatocarcinogenesis in transgenic mice. Liver Int 31: 303-312, 2011.

21. Zimmerman ZF, Moon RT and Chien AJ: Targeting Wnt pathways in disease. Cold Spring Harb Perspect Biol: Nov 1, 2012 (Epub ahead of print).

22. Herr P, Hausmann G and Basler K: WNT secretion and signalling in human disease. Trends Mol Med 18: 483-493, 2012.

23. Hayakawa Y, Hirata Y, Nakagawa H, et al: Apoptosis signal-regulating kinase 1 and cyclin D1 compose a positive feedback loop contributing to tumor growth in gastric cancer. Proc Natl Acad Sci USA 108: 780-785, 2011.

24. Santarius T, Shipley J, Brewer D, et al: A census of amplified and overexpressed human cancer genes. Nat Rev Cancer 10: 59-64, 2010.

25. Vaites LP, Lee EK, Lian Z, et al: The Fbx4 tumor suppressor regulates cyclin D1 accumulation and prevents neoplastic transformation. Mol Cell Biol 31: 4513-4523, 2011.

26. Wang C, Lisanti MP and Liao DJ: Reviewing once more the c-myc and Ras collaboration: converging at the cyclin D1-CDK4 complex and challenging basic concepts of cancer biology. Cell Cycle 10: 57-67, 2011.

27. Parekh P, Motiwale L, Naik N and Rao KV: Downregulation of cyclin D1 is associated with decreased levels of p38 MAP kinases, Akt/PKB and Pak1 during chemopreventive effects of resveratrol in liver cancer cells. Exp Toxicol Pathol 63: 167-173, 2011.

28. Huang S and He X: The role of microRNAs in liver cancer progression. Br J Cancer 104: 235-240, 2011.

29. Pang RW and Poon RT: Diagnosis: Novel prognostic biomarkers in hepatocellular carcinoma. Nat Rev Gastroenterol Hepatol 9: 691-692, 2012.

30. Xu GG and Etzkorn FA: Pin1 as an anticancer drug target. Drug News Perspect 22: 399-407, 2009.

31. Brembeck FH, Rosário M and Birchmeier W: Balancing cell adhesion and Wnt signaling, the key role of beta-catenin. Curr Opin Genet Dev 16: 51-59, 2006.

32. Shen M, Stukenberg PT, Kirschner MW and Lu KP: The essential mitotic peptidyl-prolyl isomerase Pin1 binds and regulates mitosis-specific phosphoproteins. Genes Dev 12: 706-720, 1998.

33. Takahashi K, Uchida C, Shin RW, et al: Prolyl isomerase, Pin1: new findings of post-translational modifications and physiological substrates in cancer, asthma and Alzheimer's disease. Cell Mol Life Sci 65: 359-375, 2008.

34. Inagawa S, Itabashi M, Adachi S, et al: Expression and prognostic roles of beta-catenin in hepatocellular carcinoma: correlation with tumor progression and postoperative survival. Clin Cancer Res 8: 450-456, 2002.

35. David CJ and Manley JL: Alternative pre-mRNA splicing regulation in cancer: pathways and programs unhinged. Genes Dev 24: 2343-2364, 2010. 